\title{
Effect of Ferulic Acid on Bladder Over Activity in Diabetic Rat
}

\author{
SHEREEN M. SAMIR, M.D. and ABEER F. MOSTAFA, M.D. \\ The Department of Medical Physiology, Faculty of Medicine, Mansoura University, Egypt
}

\begin{abstract}
Background: Diabetic bladder dysfunction (DBD) shows a change in the neurotransmission patterns which could be of great importance for drug development.

Aim of Study: This study aims to explore whether cholinergic or non-adrenergic non-cholinergic (NANC) pathways are altered in their participation in mediating the contraction of diabetic urinary bladder and if ferulic acid could improve DBD.

Material and Methods: Rats were divided into three groups $(\mathrm{n}=12)$ : Streptozotocin induced diabetic group, diabetic with ferulic acid supplemented group, and age matched control group. At the end of 10 weeks, blood samples were collected, and the bladders were removed, weighed, used to measure TBARS reduced glutathione (GSH), and super oxide dismutase (SOD) in bladder homogenate and to record contractility of bladder strips.

Results: Diabetic rats received ferulic acid expressed significant reduction in blood glucose, fluid intake, urine output and improvement in bladder wt/body wt. ratio and oxidative stress markers. Ferulic group showed significant improvement in spontaneous contractility and bladder sensitivity to different agonist and antagonists when compared to those of diabetic group. The purinergic as well as cholinergic component are significantly decreased in FA treated rats than in diabetic ones which could be explained by its antioxidant activity that ameliorates oxidative stress associated with diabetes. So, in Conclusion: FA could be considered as a beneficial adjuvant in lines of DBD treatment.
\end{abstract}

Key Words: Diabetic bladder dysfunction (DBD) - Ferulic acid (FA) - Non-adrenergic non-cholinergic (NANC) pathway-Cholinergicpathway-TBARS.

\section{Introduction}

DIABETIC bladder dysfunction (DBD) is one of the most common and costly consequences of diabetes mellitus (DM) [1]. More than half of diabetic patients have been presented with urological symptoms, even among the asymptomatic ones. Diabetic-induced autonomic neuropathy has shown to be the reliable cause of detrusor muscle

Correspondence to: Dr. Shereen M. Samir, E-Mail: dr.shery98@yahoo.com over activity that is associated with urinary frequency and urgency $[2,3]$. Bladder contraction is mediated mainly by cholinergic pathway and to a less extent by non-adrenergic non-cholinergic (NANC) pathways [4]

The main excitatory transmitter known as NANC induces purinergic contraction is ATP [5] Several researchers had noticed that in pathological detrusor muscle associated with benign prostatic enlargement, detrusor hyper or hposensitivity, interstitial inflammation of bladder, and chronic paraplegia, the cholinergic and purinergic components have been changed [6-8]. In abnormally functioning bladders, the change in the pattern of neurotransmission could be of high importance for drug development. Urinary frequency and urgency in diabetic patients are common symptoms that recently found to be resistant to cholinolytics [5] Therefore, involvement of non-cholinergic components may be present.

Ferulic acid (FA), 4-hydroxy-3-methox-ycinnamic acid, one member of the phenolic acids family that found in grains, fruits and vegetables. FA concentration in cereal grains can reach $2 \mathrm{~g} / \mathrm{kg}$ dry weight [9]. Over the last years, many researchers have found the antioxidant nature of FA that can scavenge free radicals and stimulate the cellular stress response by up-regulating many cytoprotective pathways, such as heat shock protein 70 , the proto-oncogene Akt, heme oxygenase- 1 and extracellular signal-regulated kinase 1/2 [10]. Moreover, FA exerts its antioxidant effect through inhibiting the cytotoxic enzymes expression and activity, such as cyclooxygenase-2 and caspases [11]. Based on these studies, FA has been suggested to be added as a potential supplementation for several diseases associated with inflammation and oxidative stress including diabetes, cardiovascular disease, metabolic syndrome, Alzheimer's disease and cancer [12-16]. Reports have showed there are overproduc- 
tion of reactive oxygen species (ROS) and impairment of anti-oxidant enzymes activities in diabetic animal tissues that could be one of the most possible causes responsible for the different pathologies associated with diabetes $[\mathbf{1 7 , 1 8}]$.

In the present study, we used streptozotocin (STZ)-induced type 1 diabetic rat model to explore whether cholinergic or NANC pathways are altered in their participation in mediating the contraction of diabetic urinary bladder. Also, to find out if ferulic acid could improve the diabetic bladder dysfunction.

\section{Patients and Methods}

\section{Experimental animals:}

Sprague-Dawley male rats (240 to $260 \mathrm{~g}, 8$ weeks old) were procured at our Medical Experimental Research Center of Mansoura University, Egypt, housed in a 12: 12-h light-dark cycle with free food and water access were used in this study. The rats were randomly distributed into three equal groups each containing 12 rats: 10 weeks diabetic rats, 10 weeks diabetic with ferulic acid supplementation $(60 \mathrm{mg} / \mathrm{kg} /$ day intragastric administration), and age matched controls (7 October to 21 December 2018).

Diabetes was induced in fasted rats by intraperitoneal injection of streptozotocin (STZ; $65 \mathrm{mg} / \mathrm{kg}$ dissolved in $0.1 \mathrm{M}$ citrate buffer, $\mathrm{pH} 4.5$ ). The control rats were injected with citrate buffer equally. Blood samples were taken from tail vein after STZ administration by $72 \mathrm{~h}$ to confirm diabetes (blood glucose $\geq 300 \mathrm{mg} / \mathrm{dl}$ ). Measurement of blood glucose levels were done by the ACCU-CHEK. The protocol of this experimental study followed Care and Use of Laboratory Animals guides (Institute for Laboratory Animal Research, National Research Council, Washington, DC and National Academy Press, no. 85-23, revised 1996). This protocol was approved by our Local Committee of Animal Care and Use (code number: R.18.10. 300).

At 10 weeks post-treatment, rats were kept in individual metabolic cages with maintained previous conditions for $24 \mathrm{~h}$ for familiarization, then a measured volume of water was given by bottles. At the end of the day, we measured water volume remained in the bottles and collected urine. Then, we calculated the water volume consumed, and the voided urine volume for each rat.

\section{Bladder contraction experiment:}

After weighing all rats, decapitation under 4\% isoflurane inhalation anesthesia was performed after the injection of STZ by 10 weeks. Immediately, Blood samples were collected from hearts for blood glucose measurement. After that, opening the lower abdomen and removing bladders then were weighed and half of them were kept in Krebs solution for contractility experiments. The other half were washed in ice cold saline, patted dried and persevered at $-80^{\circ} \mathrm{C}$ for determination of TB ARS, GSH, and SOD.

For in vitro contraction record, from each bladder two strips of detrusor muscle were used. They were prepared by excisions on the mid-parts of the anterior and posterior bladder surfaces $(8-10 \mathrm{~mm}$ in length and $2-3 \mathrm{~mm}$ in width). The strips were hold vertically in a $20 \mathrm{ml}$ organ bath with Krebs solution maintained at $37^{\circ} \mathrm{C}$ aerated with carbogen (i.e., $5 \%$ carbon-dioxide $+95 \%$ oxygen gas mixture) and tied to a fixed metal hook at the bottom end and to an isometric transducer at the top end, under $1 \mathrm{~g}$ resting tension, using a silk thread. The isometric transducer was connected to a bridge amplifier and to the Power Lab data acquisition system with chart 7 software (AD Instrument, power lab 4/30, Australia). Each strip was left for 45-60min as equilibration period, through this period time changing the bathing physiological solution every $15 \mathrm{~min}$, before graded concentrations of acetylcholine (ACh) and other drugs were used.

After reaching a stable baseline, dosageresponse curves using ACh $\left(10^{-8}-10^{-4} \mathrm{M}\right)$ were done by adding 10 Leach ACh concentration to the bath as soon as the response reaches a plateau. To test the viability of the strips, a single concentration of $\mathrm{KCl}(120 \mathrm{mM} / \mathrm{L})$ were used at the start and end of the experiments. To evaluate cholinergic contraction, 1 Mropine (non-specific muscarinic receptor blocker) was added to solution. While, the purinergic component of contraction was evaluated by adding $\alpha, \beta$-methylene-ATP $(\alpha, \beta$-MeATP; 10 M) Also, tetrodotoxin (TTX; 1 M) vas added to confirm the neurogenic mediation of the contraction [19].

\section{Biochemical analysis:}

Determination of glucose in serum was performed according to Trinder method using enzymatic glucose oxidase [18], TBARS was determined in bladder homogenates according to Kodama et al., [21], reduced glutathione (GSH) was measured in homogenate according to Beutler et al., methodology [22] , and super oxide dismutase (SOD) was measured in tissue homogenate according to the method of Nandi and Chatterjee [23]. 


\section{Drugs and chemicals:}

The pharmacological agents that were used in this experiment are: STZ, acetylcholine, atropine, $\alpha, \beta$-MeATP, TTX and ferulic acid. The composition of the Krebs buffer was as follows (in mM): 133 $\mathrm{NaCl}, 4.7 \mathrm{KCl}, 2.5 \mathrm{CaCl} 2,1.35 \mathrm{NaH} 2 \mathrm{PO} 4,0.6$ $\mathrm{MgSO} 4,16.3 \mathrm{NaHCO} 3$, and 7.8 dextrose. All agents were purchased from Sigma Aldrich (St. Louis, MO).

\section{Statistical analysis:}

Analysis of the data was done by Statistical Package for Social Science software computer program version 22 (SPSS, Inc., Chicago, IL, USA. Presentation of the data were in the form of mean and standard deviation. The Percentage of change after blockers was calculated as the portion of the total contraction inhibited by atropine, $\alpha, \beta$ MeATP or TTX divided by the total contraction for each bladder strip in the same period time. For compar- ing between two different groups, student's $t$-test (unpaired) was used. While, for comparing more than two groups, one way Analysis of variance (ANOVA) and tukey were used. Data was considered statistically significant when $p$-value was less than 0.05 .

\section{Results}

Table (1) showed significant increase in serum level of glucose in diabetic group when compared with the age-matched control group, while diabetic rats received ferulic acid expressed significant reduction $(p<0.001)$ in blood glucose as compared to the diabetic ones. Also, by analyzing the parameters measured in bladder homogenate, results revealed that diabetic animals showed significant increase in TBARS and decrease in both GSH and SOD as compared to control rats. Meanwhile, FA treated group showed significant $(p<0.001) \mathrm{im}-$ provement in TBARS, GSH and SOD levels.

Table (1): Serum glucose and bladder homogenates levels of TBARS, reduced glutathione (GSH) and super oxide dismutase (SOD) in different studied groups

\begin{tabular}{llccc}
\hline $\begin{array}{l}\text { Group } \\
(\mathrm{n}=12)\end{array}$ & $\begin{array}{c}\text { Bl. Glucose } \\
(\mathrm{mg} / \mathrm{dl})\end{array}$ & $\begin{array}{c}\text { TBARS } \\
(\mathrm{mM} / 100 \mathrm{~g} \text { of tissue })\end{array}$ & $\begin{array}{c}\text { GSH } \\
(\mathrm{mg} / 100 \mathrm{~g} \text { tissue })\end{array}$ & $\begin{array}{c}\text { SOD } \\
(\text { U/mg protein })\end{array}$ \\
\hline $\mathrm{C}$ & $89.4 \pm 5.73$ & $4.05 \pm 0.23$ & $29.48 \pm 0.99$ & $13.47 \pm 0.82$ \\
$\mathrm{DM}$ & $385.2 \pm 31.7 *$ & $14.32 \pm 0.55^{*}$ & $12.72 \pm 0.91^{*}$ & $5.83 \pm 0.65^{*}$ \\
$\mathrm{DM}+\mathrm{FA}$ & $163.5 \pm 27.7 * \#$ & $6.02 \pm 0.38^{*} * \#$ & $26.18 \pm 0.63^{*}$ & $10.82 \pm 0.9 * \#$ \\
\hline
\end{tabular}

Values are expressed as means \pm SD.

Test used: One way ANOVA followed by post-hoc tukey. C: Control group.

By analyzing the general characteristics in different experimental groups, Table (2) showed that diabetic rats expressed significant reduction in their body weight at the end of experimental period, otherwise FA treated group showed significant increase in final body weight as compared to their initial one. By measuring the bladders' weights, diabetic bladders showed significant increase when compared to control ones that was reflected on bladder $\mathrm{wt} / \mathrm{body} \mathrm{wt}$. ratio. This ratio
DM: Diabetic group and DM+FA: Diabetic with ferulic acid. *Significantly different from control group.

\# Significantly different from diabetic group $(p<0.05)$

expressed significant increase in diabetic group more than age-matched control that was improved significantly in FA treated group when compared to the diabetic one.

As regard fluid intake and urine output results, diabetic rats expressed higher levels in both parameters than control ones, while treatment with FA resulted in significant improvement in fluid intake and urine output as compared to diabetic animals (Table 2).

Table (2): General characteristics of 10 weeks diabetic, diabetic treated with ferulic acid, and control rats.

\begin{tabular}{lcccccc}
\hline $\begin{array}{l}\text { Group } \\
(\mathrm{n}=12)\end{array}$ & $\begin{array}{c}\text { Initial weight } \\
(\mathrm{g})\end{array}$ & $\begin{array}{c}\text { Final weight } \\
(\mathrm{g})\end{array}$ & $\begin{array}{c}\text { Bladder weight } \\
(\mathrm{mg})\end{array}$ & $\begin{array}{c}\text { Bladder Wt/Body } \\
\mathrm{Wt}(\mathrm{mg} / \mathrm{g})\end{array}$ & $\begin{array}{c}\text { Fluid Intake } \\
(\mathrm{ml} / 24 \mathrm{~h})\end{array}$ & $\begin{array}{c}\text { Urine Output } \\
(\mathrm{ml} / 24 \mathrm{~h})\end{array}$ \\
\hline $\mathrm{C}$ & $245.8 \pm 4.17$ & $466.0 \pm 27.56 \S$ & $81.71 \pm 3.97$ & $0.175 \pm 0.014$ & $48.33 \pm 8.17$ & $15.58 \pm 1.72$ \\
$\mathrm{DM}$ & $255.0 \pm 4.14$ & $218.7 \pm 4.58 \S^{*}$ & $151.8 \pm 4.07^{*}$ & $0.696 \pm 0.041^{*}$ & $178.2 \pm 7.25^{*}$ & $129.6 \pm 3.85^{*}$ \\
$\mathrm{DM}+\mathrm{FA}$ & $251.3 \pm 5.15$ & $333.7 \pm 28.61 \S^{*} \#$ & $102.5 \pm 6.5 * \#$ & $0.390 \pm 0.032 * \#$ & $76.33 \pm 8.62 * \#$ & $31.33 \pm 4.2^{*} \#$ \\
\hline
\end{tabular}

Values are expressed as means \pm SD.

Test used: One way ANOVA followed by post-hoc tukey.

C: Control group.
DM: Diabetic group and DM+FA: Diabetic with ferulic acid.

* Significantly different from control group.

\# Significantly different from diabetic group $(p<0.05)$. 
Fig. (1) represented a comparison in spontaneous bladder contraction among different experimental groups. This comparison revealed that diabetic bladder contractions showed significant increase in basal frequency and amplitude as compared to age-matched control bladder contractions. However, spontaneous bladder contractions of diabetic rats treated with FA showed significant reduction in both frequency and amplitude when compared to those of diabetic group, while by comparing to age-matched control bladder contractions there were no significant change in frequency.
Fig. (2) represented cumulative concentrationdependent contractions in bladder strips of different experimental groups in response to increasing concentrations of acetylcholine $\left(10^{-8} 10^{-4} \mathrm{M}\right)$. Results revealed that ACh induced greater contractions of the diabetic bladders than their counterparts isolated from control and diabetic treated with ferulic acid rats. As shown in curves (Fig. 3), the diabetic bladder strips showed characteristic sigmoid dose dependent increase in tone and frequency of contractions, yielding an Emax of $10^{-6} \mathrm{M}$, while that of the other two groups it was $10^{-5} \mathrm{M}$.
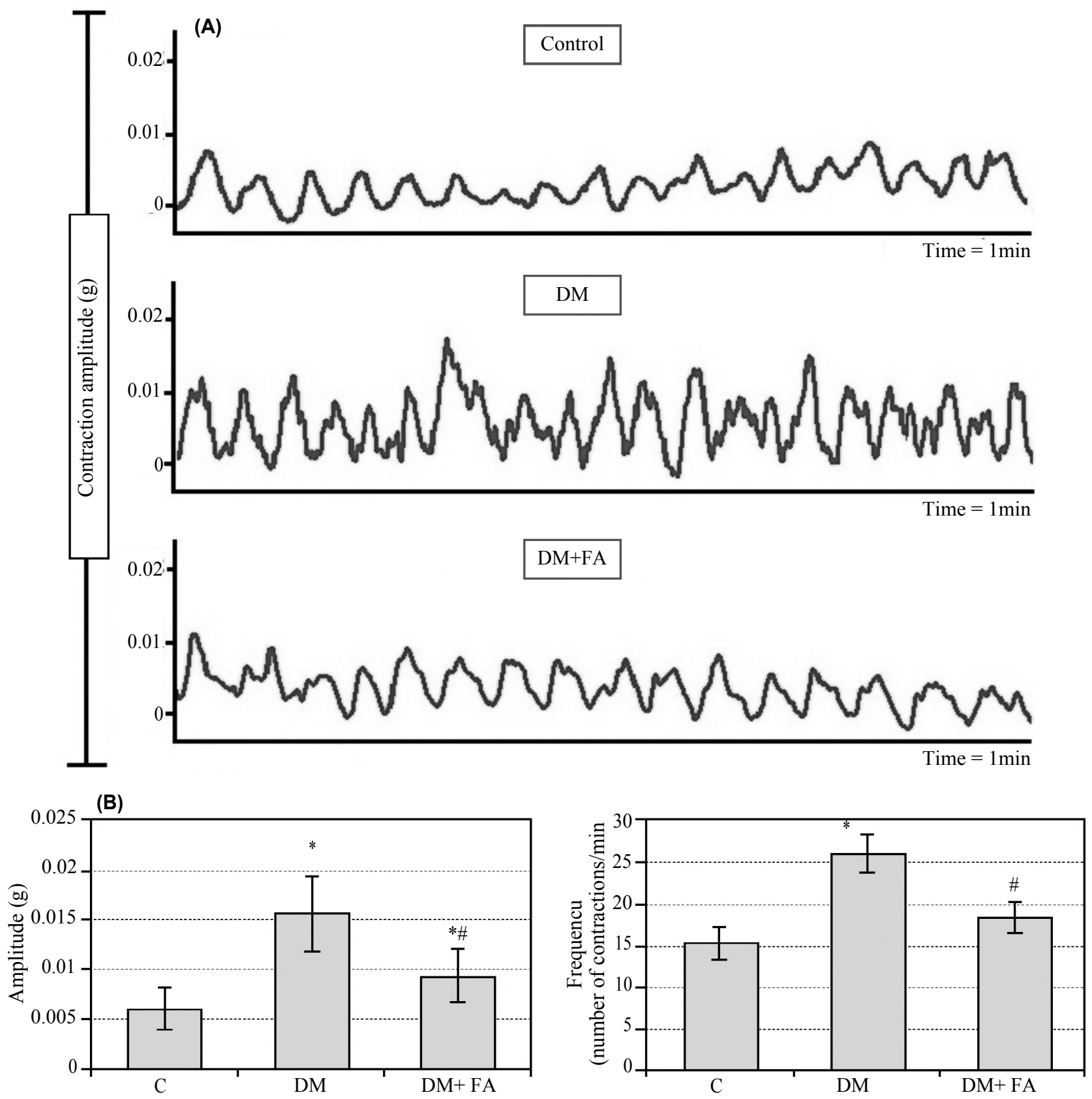

Fig. (1A): Spontaneous contractions of the rat bladder strips from control (C), diabetic (DM), and diabetic treated with ferulic acid (DM+FA) groups over a period of one minute. (B): Histograms show the comparison among different experimental groups (amplitude and frequency). Test used: One way ANOVA followed by post-hoc tukey. Values are expressed as means $\pm \mathrm{SD}$. 


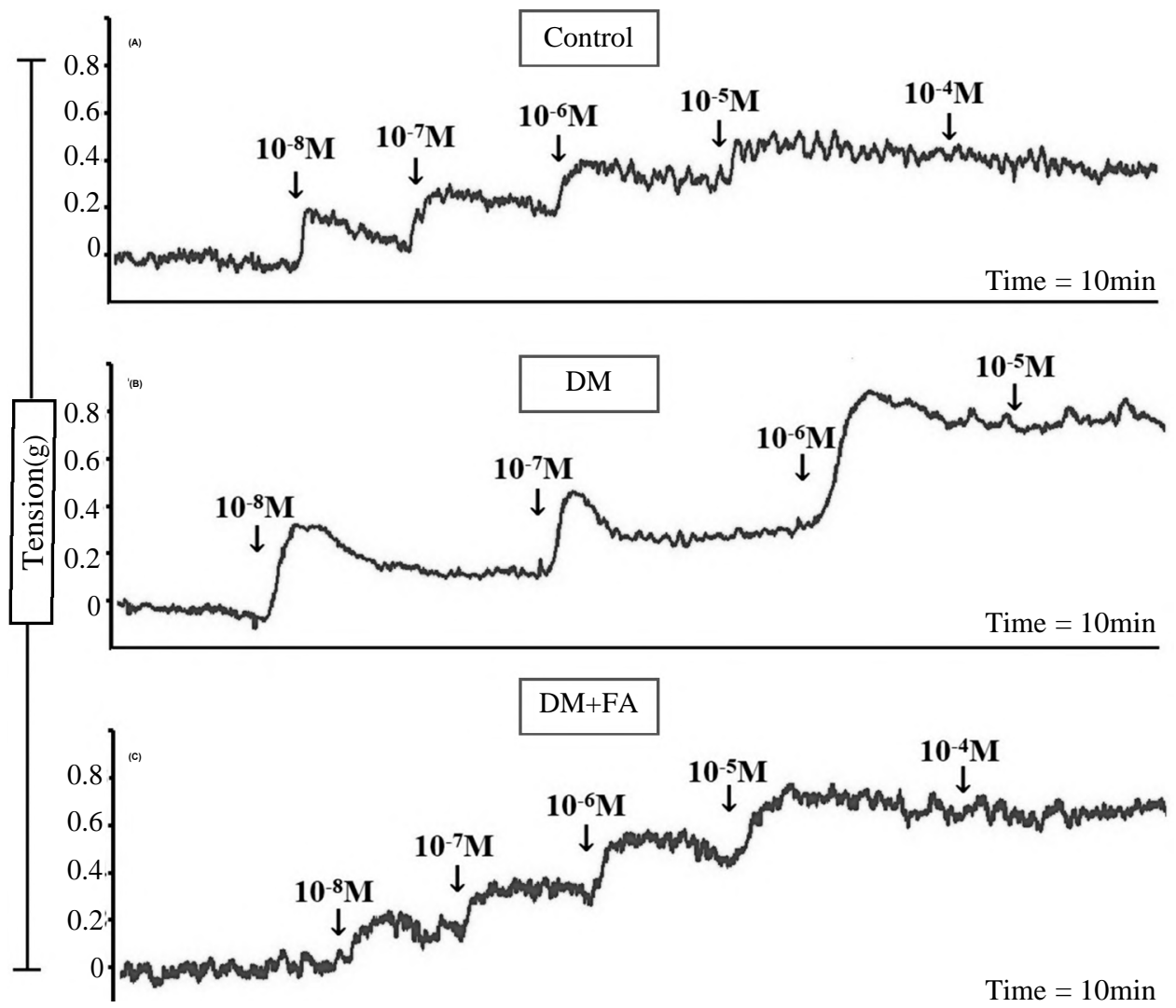

Fig. (2): Cumulative dosage-response curves of rat bladder strips from control(C), diabetic (DM), and diabetic treated with ferulic acid (DM+FA) groups using ACh (10-8-10-4 M).
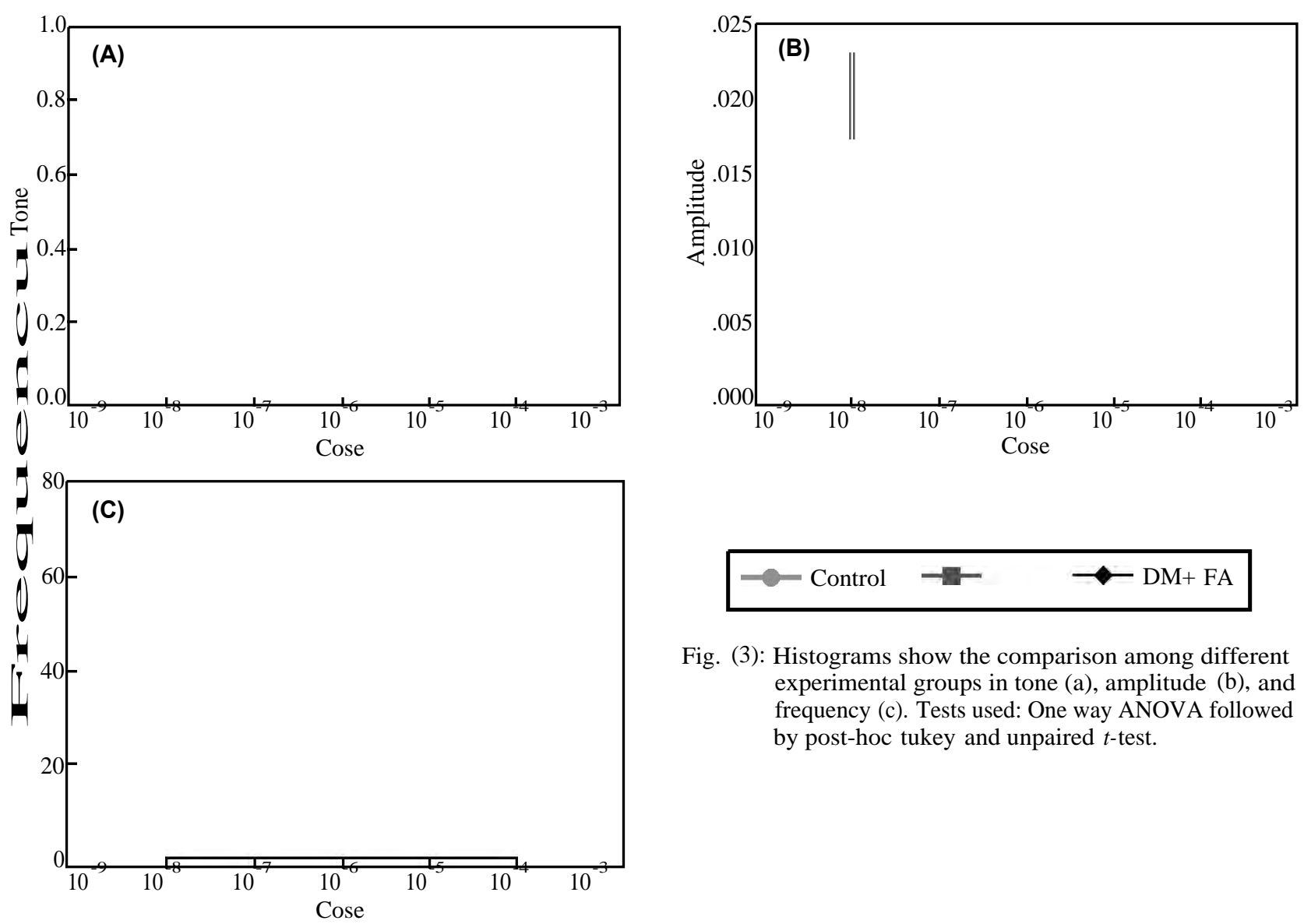

Fig. (3): Histograms show the comparison among different experimental groups in tone (a), amplitude (b), and frequency (c). Tests used: One way ANOVA followed by post-hoc tukey and unpaired $t$-test. 
Figs. $(4,5)$ represented the effect of different blockers on spontaneous contractions of bladder strips. By addition of 1 Mropine (non-specific muscarinic receptor blocker), the contractions of diabetic bladders were reduced by $45.5 \pm 1.5 \%$, $21.7 \pm 2.1 \%$ and $55.2 \pm 1.5 \%$ as regard tone, frequency and amplitude, respectively. This means an increase in the cholinergic component of diabetic bladder contraction than that of control bladder strips which accounted for $36.2 \pm 2.6 \%$ in tone, $15 \pm 1.4 \%$ in frequency and $30.5 \pm 3.4 \%$ in amplitude. However, bladders of diabetic rats treated with FA showed significant decrease in the cholinergic component as compared with the non-treated diabetic ones.

The purinergic component of contraction was blocked by addition of $10 \quad \beta$-MeATP yielding inhibition in diabetic strips contractions equal $60.5 \pm 3.3 \%, 45 \pm 2.6 \%$ and $78.8 \pm 4.4 \%$ concerning tone, frequency and amplitude, respectively. While, in diabetic treated with FA contractions the purinergic component accounted for $50.8 \pm 2.2 \%$ in tone, $36.3 \pm 1.9 \%$ in frequency and $61.8 \pm 2.2 \%$ in amplitude which approached results of control group.

While, by addition of $1 \mathrm{MTX}$ there was no significant change in spontaneous contractions in control and diabetic treated with FA bladder strips. However, in diabetic group results represented inhibition in spontaneous contraction around $10.7 \pm 1.8 \%$ in tone, $5.7 \pm 2.8 \%$ in frequency and $3.3 \pm 3.1 \%$ in amplitude.

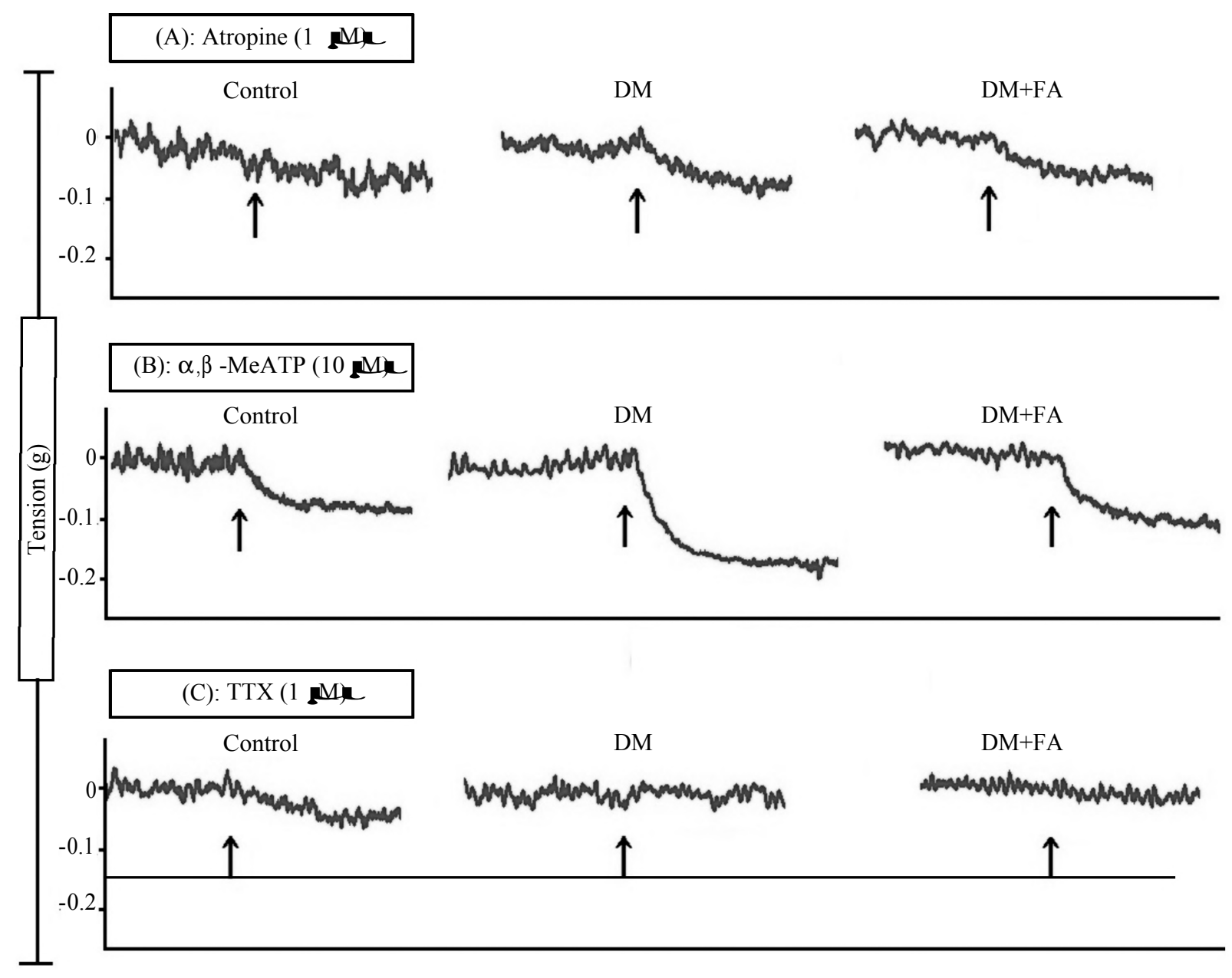

Fig. (4): Effects of different blockers on spontaneous contractions of rat bladder strips from control (C), diabetic (DM), and diabetic treated with ferulic acid (DM+FA) groups. a: Atropine (1 b: $\alpha, \beta$-MeATP (10 

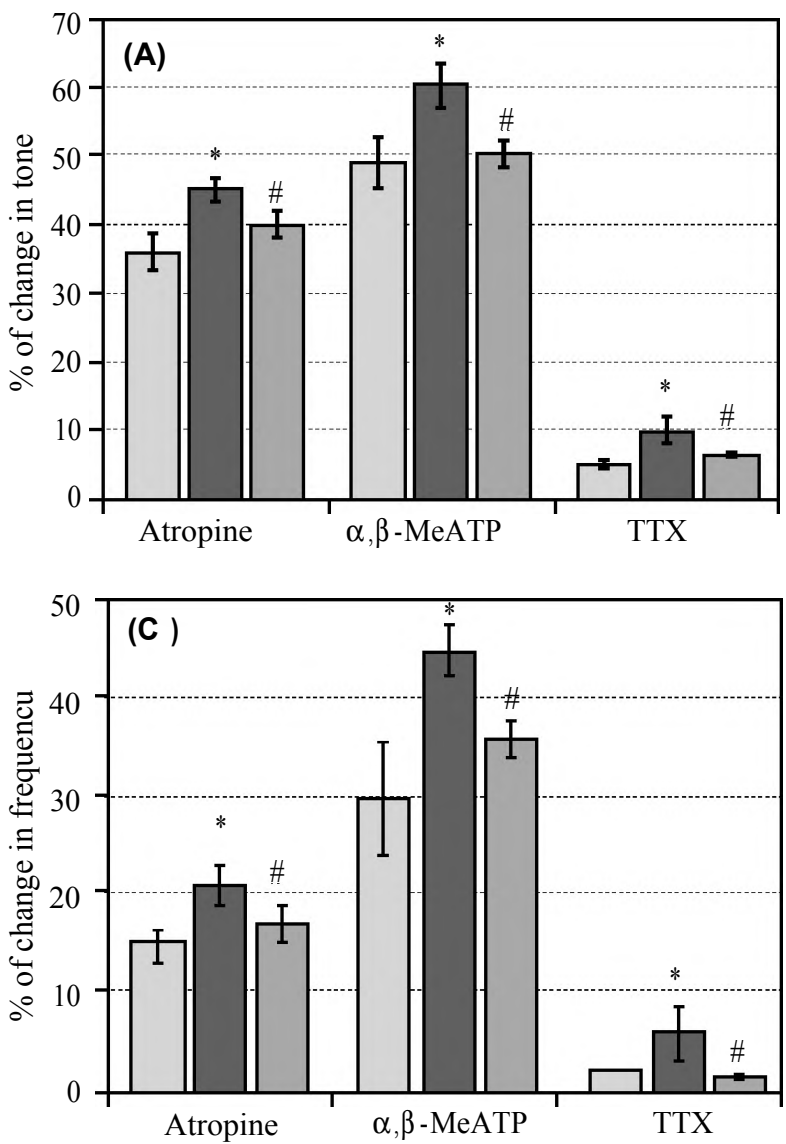

Discussion

Diabetes causes significant functional and morphometrical changes in the bladder. The most marked changes include bladder hypertrophy, and disturbance of its voiding ability [24]. The diabetic bladders' weights were $\sim 2$ times of those from control rats. While, the ferulic treated group bladders were $\sim 1.2$ times of control bladders' weights. This highlights that ferulic acid alone may change the physical properties of the bladder which is a novel finding in this research. Liu and Daneshgari [25] noticed that the enlargement and hypertrophy of the bladder wall and lumen in the diabetic animals are likely to be compensatory to the diuretic effect of the disease. Also, they suggested that this bladder hypertrophy could result in distortion of the normal innervation pattern, including local neurogenic and myogenic changes that can be the major pathophysiological changes in DBD. Regarding to Liu and Daneshgari [25] study, our research find out that FA surprisingly shows significant improvement in the diuretic effect of diabetes as shown by decreasing the urine output in treated animals which is reflected on their bladders' weights. The significant effects of FA on fluid intake and urine output may be related to its hypoglycemic effect which could be explained by
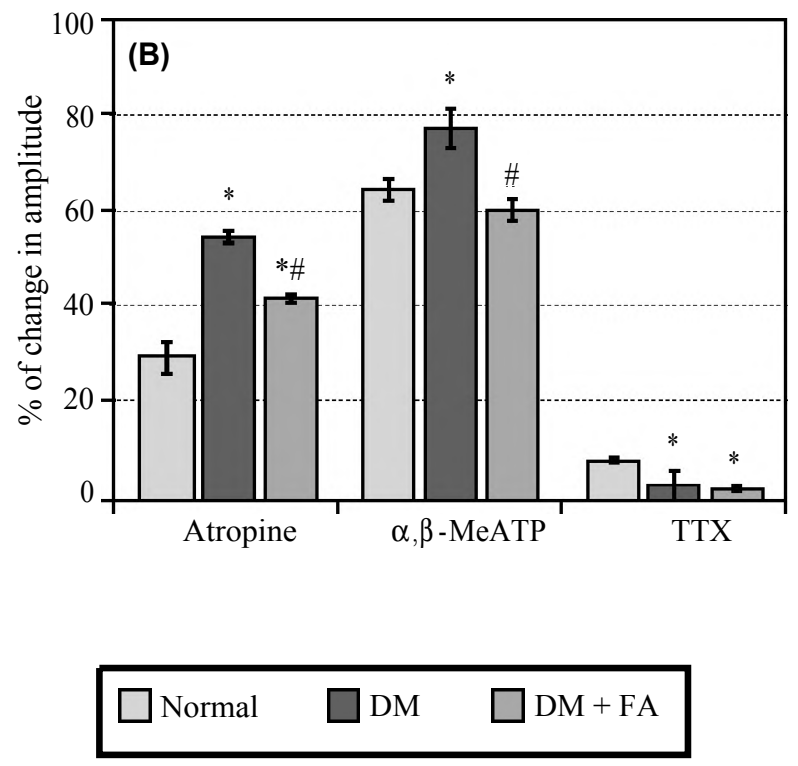

Fig. (4): Histograms show the comparison among the different experimental groups in tone (a), amplitude (b), and frequency (c). Test used: One way ANOVA followed by post-hoc tukey.

Senaphan et al., [14] who found that oral supplementation of FA improves the insulin resistance in metabolic syndrome in rats induced by high carbohydrate high fat diet. Also, according to our results we could explain the improvement in diabetic bladder weight that was expressed the degree of hypertrophy and enlargement by its antioxidant role which was indicated by improvement of GSH and SOD as well as decrease in TBARS levels in tissue homogenates.

The present study shows that the bladder spontaneous contractility of diabetic rats are greater than those of control ones. Our result is in consistent with other reports' findings about enhanced contractile responses in diabetic rat bladder after induction of diabetes by 8 to 12 weeks [25-27] Many alterations may participate in increasing the neurogenic induced contraction in diabetic animals, including changes in bladder smooth muscles sensitivity or affinity to the cholinergic and purinergic neurotransmitters, together with changes in releasing neurotransmitters from intrinsic nerves [28] Zatalia and Sanusi [29] reported that hyperglycemia which is associated with DM is considered the main cause of imbalance between free radical formation and the ability of the body's natural antioxidants which could be another explanation 
of diabetic bladder over-activity. However, our results demonstrated that FA treated diabetic rats showed significant reduction in both frequency and amplitude of spontaneous bladder contractility when compared to the untreated diabetic contractility. This beneficial effect of FA on diabetic bladder contractility may be attributed to its antioxidant and hypoglycemic action.

Diabetic cystopathy is a well-marked complication of diabetes mellitus. It may have wide range of clinical presentations extending from detrusor hyper-reflexia in $~ 55 \%$ of diabetic patients to reduced detrusor contractility in $\sim 23 \%$ of diabetics [31]. Generally, the multifariousness of DBD that could progress from overactive to underactive is ascribed to the length of the disease. Our experimental study extended for 10 weeks after induction of diabetes which is based on previous studies as Munoz et al., [31] and Yoshizawa et al., [5] who reported that diabetes in rats is considered to be early up to 4-12 weeks from the date of induction of diabetes.

There are many controversies regarding the cholinergic and purinergic contributions in diabetic bladder contractility. Pontari et al., [31] reported a $70 \%$ increase in the density of muscarinic (M2) receptors within 2 weeks of the induction of diabetes in rats. While other studies $[25,32]$ reported that the purinergic contribution in diabetics is higher than cholinergic one. Additionally, our study results obviously demonstrate that spontaneous contractions were inhibited $\sim 45.5 \%$ by atropine and $\sim 60.3 \%$ by $\alpha, \beta$-MeATP in detrusor from diabetic animals. Moreover, specimens from control and FA treated animals showed lesser cholinergic contribution than diabetics that could be expressed as inhibition of spontaneous contractility by atropine up to $\sim 36 \%$ and $\sim 40.8 \%$ respectively. Also, the purinergic contribution in control and treated groups were lesser than the diabetic ones reaching around $49 \%$ and $50.6 \%$ inhibition of contractility by $\alpha, \beta$-MeATP. Also, the diabetic detrusor contractility expressed greater residual NANC contractile response than those from other groups which was inhibited by TTX.

These results supported with dose response curves that showed high responsiveness of diabetic bladder to A.Ch which reaching Emax at lower concentration than that of control and ferulic treated bladders. Our results could be explained by Yuan et al., [33] study that found the over-activity and high response of diabetic bladder to agonists may be due to upregulation of the muscarinic receptors especially $\mathrm{M}_{2}$ and $\mathrm{M}_{3}$, together with increase in neurotransmitter release, increased sensitivity to calcium, and enhanced calcium channel activity. The present results indicated that there is an increase in sensitivity of diabetic bladder which may be attributed to concomitant upregulation in purinergic $(\mathrm{P} 2 \mathrm{X})$ and muscarinic receptors. It is interesting to note that the alteration of purinergic receptor predominates than that of muscarinic receptor.

\section{Conclusion:}

Diabetic bladder dysfunction (DBD) is one of the most marked and costly consequences of diabetes mellitus (DM). By treating the diabetic rats with ferulic acid, the bladder spontaneous contractility as well as its responsiveness to A.Ch is improved. The purinergic as well as cholinergic component are significantly decreased in FA treated rats than in diabetic ones. These results could be explained by its antioxidant activity that ameliorates oxidative stress associated with diabetes. So, FA could be considered as a beneficial adjuvant in lines of DBD treatment.

Acknowledgements: The Physiology Department and Medical Experimental Research Center of Mansoura University are acknowledged for their significant contribution to the experimental part of the study.

Author contribution: Shereen M. Samir and Abeer F. Mostafa designed and performed the research; also, wrote the paper and Mohamed R. Mahdi analyzed the data.

Conflict of interest: The authors declare that there is no conflict of interest.

\section{References}

1- LIU G. and DANESHGARI F.: Diabetic bladder dysfunction. Chin. Med. J. (Engl.), 127: 1357-1364. Pmid: 24709194, 2014.

2- BANSAL R., AGARWAL M.M., MODI M., MANDAL A.K. and SINGH S.K.: Urodynamic profile of diabetic patients with lower urinary tract symptoms: Association of diabetic cystopathy with autonomic and peripheral neuropathy. Urology, 77: 699-705, 2011.

3- INAN E.A., ELLENBROEK J.H. and MICHEL M.C.: A systematic review of urinary bladder hypertrophy in experimental diabetes: Part I. Streptozotocin-induced rat models. Neurourology and Urodynamics, 37: 1212-1219. doi: 10.1002/nau.23490, 2018.

4- KULLMANN F.A., DAUGHERTY S.L. DE GROAT W.C. and BIRDER L.A.: Bladder Smooth Muscle Strip Contractility as a Method to Evaluate Lower Urinary Tract Pharmacology. J. Vis. Exp., 90: 51807. doi: 10. 3791/51807, 2014. 
5- YOSHIZAWA T., HAYASHI Y., YOSHIDA A., YOSHIDA S., ITO Y., YAMAGUCHI K., YAMADA S. and TAKAHASHI S.: Concomitant alteration in number and affinity of P2X and muscarinic receptors are associated with bladder dysfunction in early stage of diabetic rat. International Urology and Nephrology, 50: 451-458. doi.org/ 10.1007/s11255-018-1800-6, 2018.

6- BARBOSA J.A.B.A., REIS S.T., NUNES M., FERREIRA Y.A., LEITE K.R., NAHAS W.C., SROUGI M. and ANTUNES A.A.: The Obstructed Bladder: Expression of Collagen, Matrix Metalloproteinases, Muscarinic Receptors, and Angiogenic and Neurotrophic Factors in Patients With Benign Prostatic Hyperplasia. Urology, 106: 167172. doi: 10.1016/j., 2017.

7- SUN Y. and CHAI T.C.: Augmented extracellular ATP signaling in bladder urothelial cells from patients with interstitial cystitis. Am. J. Physiol. Cell. Physiol., 290: C27-C34. doi:10.1152/ajpcell.00552.2004, 2006.

8- YOKOTA T. and YAMAGUCHI O.: Changes in Cholinergic and Purinergic Neurotransmission in Pathologic Bladder of Chronic Spinal Rabbit. J. Urology, 156: (5): 1862-1866. doi.org/10.1016/S0022-5347(01)65554-X.. 1996.

9- KUMAR N and PRUTHI V.: Potential applications of ferulic acid from natural sources. Biotechnol. Rep., 4: 86-93. doi: 10.1016/j.btre, 2014.

10- MANCUSO C. and SANTANGELO R.: Ferulic acid: Pharmacological and toxicological aspects. Food and Chemical Toxicology, 65: 185-195. doi: 10.1016/j.fct., 2014.

11- PEREZ-TERNERO C., WERNER C.M., NICKEL A.G., HERRERA M.D., MOTILVA M.J., BÖHM M., ALVAREZ DE SOTOMAYOR M. and LAUFS U.: Ferulic acid, a bioactive component of rice bran, improves oxidative stress and mitochondrial biogenesis and dynamics in mice and in human mononuclear cells. J. Nutr. Biochem., 48: 51-61. doi: 10.1016/j.jnutbio, 2017.

12- BUMRUNGPERT A., LILITCHAN S., TUNTIPOPIPAT S. and TIRAWANCHAI N.: Komindr Ferulic Acid Supplementation Improves Lipid Profiles, Oxidative Stress, and Inflammatory Status in Hyperlipidemic Subjects: A Randomized, Double-Blind, Placebo-Controlled Clinical Trial. S. Nutrients, 2: 10 (6). pii: E713. doi: 10.3390/ nu10060713, 2018

13- BAIRAGI U., MITTAL P., SINGH J. and MISHRA B.: Preparation, characterization, and in vivo evaluation of nano formulations of ferulic acid in diabetic wound healing. Drug. Dev. Ind. Pharm., 44 (11): 1783-1796. doi: 10.1080/03639045, 2018.

14- SENAPHAN K., KUKONGVIRIYAPAN U., SANGARTIT W., PAKDEECHOTE P., PANNANGPETCH P., PRACHANEY P., GREENWALD S.E. and KUKONGVIRIYAPAN V.: Ferulic Acid Alleviates Changes in a Rat Model of Metabolic Syndrome Induced by HighCarbohydrate, High-Fat Diet. Nutrients., 7 (8): 6446-64. doi: 10.3390/nu7085283, 2015.

15- MENG G., MENG X., MA X., ZHANG G., HU X., JIN A., ZHAO Y. and LIU X.: Application of Ferulic Acid for Alzheimer's Disease: Combination of Text Mining and Experimental Validation. Front Neuroinform, 29: 1231. doi: 10.3389/fninf, 2018.
16- GAO J., YU H., GUO W., KONG Y., GU L., LI Q., YANG S., ZHANG Y. and WANG Y.: The anticancer effects of ferulic acid is associated with induction of cell cycle arrest and autophagy in cervical cancer cells. Cancer Cell Int., 13:18-102. doi: 10.1186/s12935-018-0595-y, 2018.

17- ULLAH A., KHAN A. and KHAN I.: Diabetes mellitus and oxidative stress A concise review. Saudi Pharmaceutical Journal, 24 (5): 547-553, 2016.

18- NEWSHOLME P., CRUZAT V.F., KEANE K.N., CARLESSI R. and DE BITTENCOURT P.I.H.: Molecular mechanisms of ROS production and oxidative stress in diabetes. Jr Biochemical. Journal, 473 (24): 4527-4550; doi: 10.1042/BCJ20160503C., 2016.

19- KULLMANN F.A., DAUGHERTY S.L., DE GROAT W.C. and BIRDER L.A.: Bladder Smooth Muscle Strip Contractility as a Method to Evaluate Lower Urinary Tract Pharmacology. J. Vis. Exp., 90: e51807. doi:10. 3791/51807, 2014.

20- TRINDER P.: Enzymatic determination of glucose. Am. Clin. Biochem., 969 (6): 24-32, 2002.

21- KODAMA H., KURIBAYASHIY Y. and GAGNON C.: Effect of sperm lipid peroxidation on fertilization. J. Androl., 17 (2): 151-157. doi.org/10.1002/j.1939-4640 1996. tb01764.x, 1996.

22- BEUTLER E. and DURON O. KELLY B.M.: Improved method for the determination of blood glutathione. J. Lab. Clin. Med., 61: 882, 1963.

23- NANDI A. and CHATLERJEE I.B.: Assay of superoxide dismutase activity in animal tissues. J. Bio. Sci., 13 (3): 305-315. doi:10.1007/BF02712155, 1988.

24- LEE W.C., CHIANG P.H., TAIN Y.L., WU C.C. and CHUANG Y.C.: Sensory dysfunction of bladder mucosa and bladder oversensitivity in a rat model of metabolic syndrome. PLOS ONE, 7 (9): e45578. doi.org/10.1371. liour nal.pone., 0045 578, 2012.

25- LIU G. and DANESHGARI F.: Alterations in neurogenically mediated contractile responses of urinary bladder in rats with diabetes. Am. J. Physiol. Renal. Physiol., 288: F1220-F1226. doi: 10.1152/ajprenal, 2005.

26- VADHAVKAR M., GOLBIDI S., SEA J., LONGPRE M., STOTHERS L. and LAHER I.: Exercise Improves Bladder Function in Diabetic Mice. Neurourology and Urodynamics, 30: 174-182. doi: 10.1002/nau.20964, 2011.

27- LEIRIA L.O., MÓNICA F.Z., CARVALHO F.D., CLAUDINO M.A., FRANCO-PENTEADO C.F., SCHENKA A., GRANT A.D., DE NUCCI G. and ANTUNES E.: Functional, morphological and molecular characterization of bladder dysfunction in streptozotocin-induced diabetic mice: Evidence of a role for L-type voltage-operated Ca2+channels. Br. J. Pharmacol., 163: 1276-1288. doi.org/ 10.1111/j.1476-5381, 2011.

28- GOLBIDI S. and LAHER I.: Bladder dysfunction in diabetes mellitus. Frontiers in Pharmacology Cardiovascular and Smooth Muscle Pharmacology, 1 (136): 1-9, 2010.

29- XIAO N.1, HUANG Y., KAVRAN M., ELRASHIDY R.A. and LIU G.: Short-term diabetes-and diuresis-induced alterations of the bladder are mostly reversible in rats. Int. J. Urol., 22 (4): 410-5. doi: 10.1111/iju.12695, 2015. 
30- ZATALIA S.R. and SANUSI H.: The role of antioxidants in the pathophysiology, complications, and management of diabetes mellitus. Acta. Med. Indones., 45: 141-147, 2013.

31- MUNOZ A., BOONE T.B., SMITH C.P. and SOMOGYI G.T.: Diabetic plasticity of non-adrenergic non-cholinergic and P2X-Mediated rat bladder contractions. Brain. Res. Bull. 95: 40-45. doi.org/10.1016/j, 2013.

32- PONTARI M.A., BRAVERMAN A.S. and RUGGIERI M.R.: The M2 muscarinic receptor mediates in vitro bladder contractions from patients with neurogenic bladder dysfunction. Am. J. Physiol. Regul. Integr. Comp. Physiol., 286 (5): R874-R880. doi:10.1152/ajpregu, 2004.

33- TAGLIANI M., CANDURA S.M., DI NUCCI A., FRANCESCHETTI G.P., D'AGOSTINO G., RICOTTI P., FIORI E. and TONINI M.: A re-appraisal of the nature of the atropine-resistant contraction to electrical field stimulation in the human isolated detrusor muscle. Naunyn Schmiedebergs Arch. Pharmacol., 356: 750-755, 1997.

34- YUAN Z., TANG Z., CHANGXIAO H.E. and TANG W.: Diabetic cystopathy: A review. J. Diabetes, 7: 442-447, 2015.

\section{تأثير حمض الفريوليك على النشاط الزائد للمثانة البولية فى الجرذان

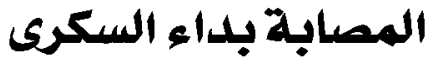

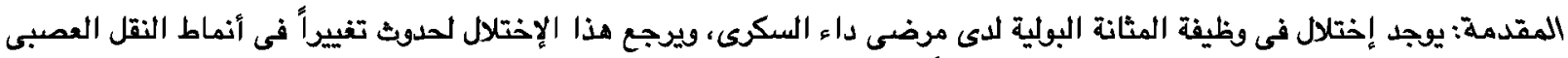
بالمثانة البولية، ولذلك فإن دراسة هذا التغيير قد تكن ذات أهمية كبيرة لتطوير الدواء المعالج لإختلال وظيفة المثانة البو لية. لذلك تهدف هذه الدراسة إلى: أ أستكثاف ما إذا كانت مسارات الأستيل كولين العصبية أو المسارات العصبية غير الكولينية والغير أدرينالية (NANC) قد تم تغيير

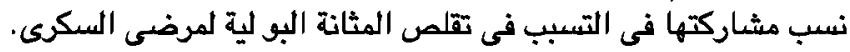
r-دراسة ما إذا كان حمض الفريو ليك يمكن أن يحسن من هذا الإختلال الوظيفى لهئ. طريقة الدراسة: لإجراء هذا البحث تمن الدراسة على حس من ذكود الجرذان البضاء، حيث تم قياس أوذانهم ثم تم تقسيمهم إلى ثلاث

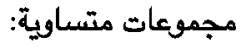
• • • المجموعة الأولى: المجموعة الضعابطة.

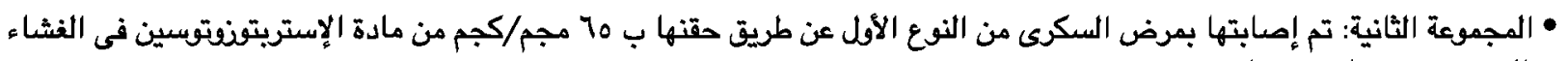

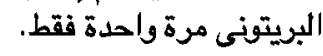

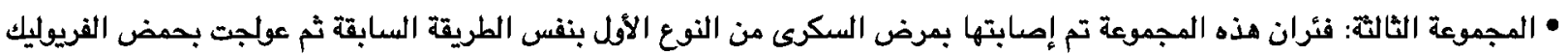

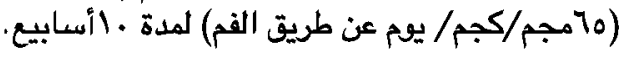

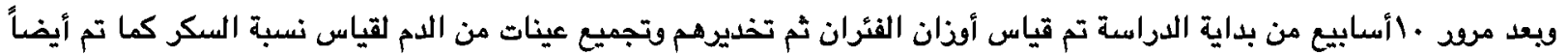

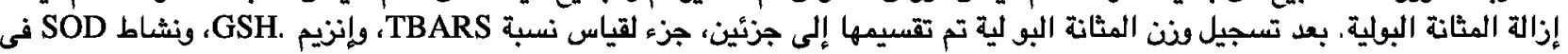

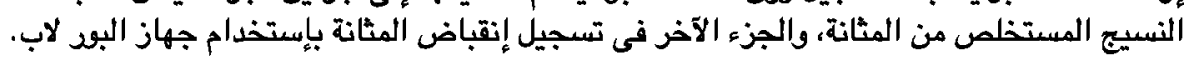

$$
\text { وأثناء الدراسة تم أيضاً حساب حجم المياه المستهلكة، وحجم البول الناتج لكل فأر. }
$$

النتائج والمناقشَّة:

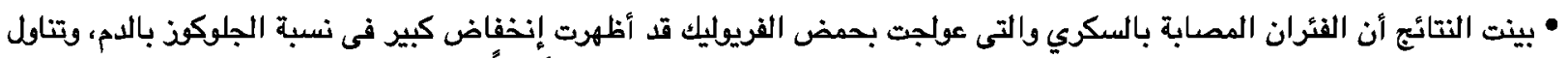

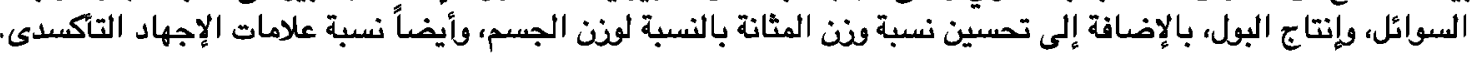

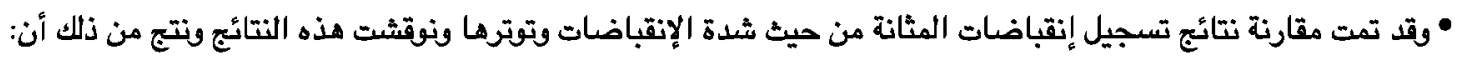

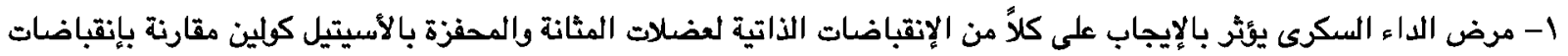
مثانة الجرذان السليمة الذاتية والمحفزة.

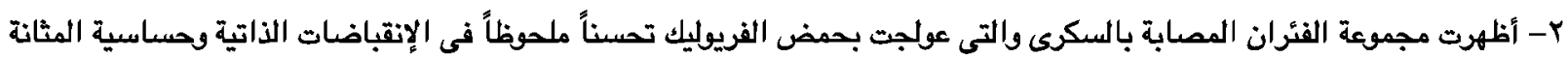

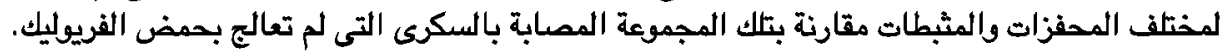

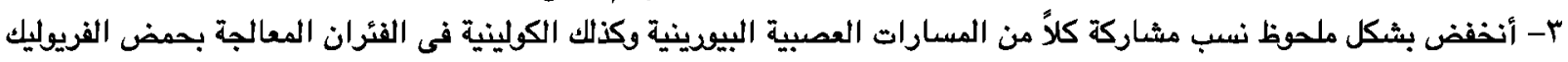

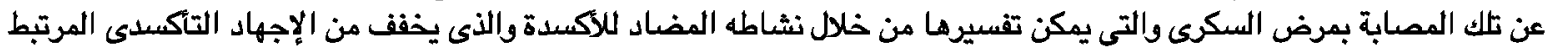
بالسكرى. الخلاصة: مما سبق نستنتج أنه يمكن أعتبار حمض الفريوليك مادة مسـاعدة ومفيدة فى علاج الخلل الوظيفى المثانة لدى مرضى السكرى. 